\title{
Detection of fibrinogen antigens with two latex techniques applied to urine concentrates ${ }^{1}$
}

\author{
MARIA BENEDETTA DONATI ${ }^{2}$, N. SEMERARO ${ }^{3}$, AND J. VERMYLEN \\ From the Laboratory of Blood Coagulation, Medical Research Department, University of Leuven, Belgium
}

SYNOPSIS Fibrinogen antigens were measured either with an agglutination inhibition method $\vec{\omega}$ (using latex particles coated with fibrinogen; Diagen test) or with a direct agglutination technique $\overline{0}$ (using latex particles coated with a mixture of anti-D and anti-E antibodies; Thrombo-Wellcotest). N Both methods were compared with the tanned red cell haemagglutination inhibition immunoassay: (TRCHII) during progressive degradation of fibrinogen with plasmin and using purified fibrinogen ${ }^{\circ}$ fragments or urine concentrates from chronic glomerulonephritis or transplanted patients. Due to the different sensitivity of the two latex techniques to fibrinogen and its plasmin derivatives, theiro combined use may be helpful to distinguish the nature of the fibrinogen-like material excreted inurine.

Many studies have recently indicated that urinary excretion of fibrin(ogen) degradation products is a valuable parameter of disease activity in some renal disorders (Clarkson, MacDonald, Petrie, Cash, and Robson, 1971; Dotremont, Vermylen, Donati, Van Damme, and Michielsen, 1972), may be helpful in evaluating the response of glomerulonephritis patients to treatment (Vermylen, Dotremont, de Gaetano, Donati, and Michielsen, 1970; Clarkson, MacDonald, Cash, and Robson, 1972), and represents a diagnostic tool during rejection crises following kidney homotransplantation (Braun and Merrill, 1968; Antoine, Neveu, and Ward, 1969; Clarkson, Morton, and Cash, 1970; Bouma, Hedner, and Nilsson, 1971; Haanen, Nováková, Wijdeveld, and van Liebergen, 1971). The development of simple, rapid and sensitive methods for detecting fibrinogen derivatives in urine is therefore of increasing interest.

In this paper two techniques using latex particles will be compared with the tanned red cell haemagglutination inhibition immunoassay (TRCHII) of Merskey, Lalezari, and Johnson (1969) on purified fibrinogen derivatives and on urine concentrates from chronic glomerulonephritis and transplanted patients.

'Supported by grant 1216 of the Fonds voor Wetenschappelijk Geneeskundig Onderzoek, Belgium.

'Present address: Laboratory for Haemostasis and Thrombosis Research, Mario Negri Institute, Via Eritrea, 62 - 20157 Milano, Italy.

'Present address: Istituto di Patologia Generale, Universita di Bari, Bari, Italy.

Received for publication 22 May 1973.

\section{Materials and Methods}

Purified human fibrinogen was a gift of Kâbr (Stockholm). Solutions of $1 \%(w / v)$ clottabifo protein were prepared in $0.1 \mathrm{M}$ phosphate buffer pH 7.4 and incubated at $37^{\circ} \mathrm{C}$ with human plasmino (Claeys, Molla, and Verstraete, 1973), at a finaß̋ concentration of $0.5 \mathrm{CTA}$ units $/ \mathrm{ml}$. At differen $\mathbb{Q}$ time intervals aprotinin (Trasylol, Bayer, Lever $\overrightarrow{\overrightarrow{0}}$ kusen) was added at a final concentration of $500 \mathrm{~KB}$ units/ml.

Purified $D$ and $E$ fragments from human fibrin ogen were obtained by DEAE-cellulose chromato graphy of an extensively degraded fibrinogeno? lysate (Nussenzweig, Seligmann, Pelmont, and Grabar, 1961; Donati, Molla, and Vermylen, 1971)

Urine concentrates were prepared as previouslyg described (Vermylen et al, 1970).

The TRCHII, the staphylococcal clumping tes음 (SCT) (Hawiger, Niewiarowski, Gurewich, and Thomas, 1970; Donati, Vermylen, and Verstraete 1971), and the measurement of the clottable protein $N$ on urine concentrates were performed as describeq elsewhere (Vermylen et al, 1970; Donati, Molla Michielsen, and Vermylen, 1973). Clottable proteinw was considered to be present in a sample when the titre in the TRCHII decreased at least eight-fold aftes incubation with thrombin and proteolysis inhibitor

The Thrombo-Wellcotest reagent was supplied? by Wellcome Reagents Limited (Beckenham and Brussels) as a suspension of latex particles coate $\phi_{\text {}}$ with rabbit antibody against $D$ and $E$ fragments 
Test samples were diluted in a $0 \cdot 1 \mathrm{M}$ glycine/saline buffer $\mathrm{pH} 8.2$ and the test was performed as suggested by the manufacturer, except that neither thrombin nor proteolysis inhibitor were added to the test samples.

The Diagen test reagents were a gift of Diagnostic Reagents Limited through the courtesy of Dr K. W. E. Denson.

The principle and the performance of this test have been described by Allington (1971a and b). The agglutination inhibition titre was transformed into concentrations of fibrinogen-like material $(\mu \mathrm{g} / \mathrm{ml})$ by comparison with a simultaneously studied standard normal plasma of known fibrinogen concentration.

\section{Results}

\section{REACTIVITY OF PURIFIED MATERIALS IN}

LATEX TECHNIQUES

The reactivity of purified fibrinogen during plasmin digestion in both latex techniques was compared to that in the TRCHII and the SCT. The figure shows the evolution of the titre in the different tests before and during the proteolysis. With the high plasmin concentration used, the reactivity in the SCT decreased very early (after one hour) whereas the

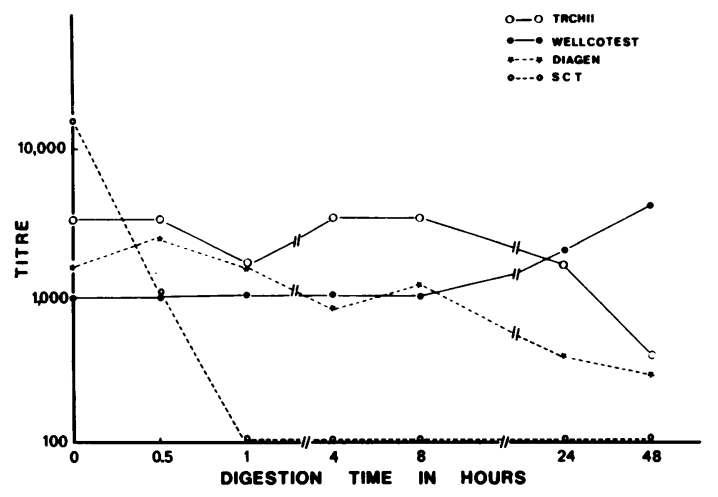

Fig Evolution of the titre in different tests during proteolysis of human fibrinogen by plasmin. titre in the three other tests remained unchanged during at least eight hours; at the stage of very extensive degradation the reactivity decreased in the TRCHII and the Diagen tests, but increased in the Thrombo-Wellcotest. These results were confirmed by the study of purified $D$ and E products: as shown in table I, the Diagen test, like the TRCHII, was highly sensitive to fibrinogen, but reacted four to eight times less with extensively proteolysed $D$ and not at all with fragment $E$. In contrast, the ThromboWellcotest was four and 60 times more sensitive to $\mathrm{D}$ and $\mathrm{E}$ respectively than to fibrinogen.

REACTIVITY OF URINARY FIBRINOGEN-LIKE MATERIAL IN LATEX TECHNIQUES

The reactivity of urinary fibrinogen-related material in the two latex techniques was studied on 67 urine concentrates, 42 from 14 transplanted patients and 25 from 14 chronic glomerulonephritis patients. Table II shows the regression lines obtained when the results of the Diagen test, of the ThromboWellcotest, and of the TRCHII were compared. In view of the different sensitivity of the latex techniques to fibrinogen and its derivatives, shown by the studies on purified systems, the reactivity in these tests of clottable and non-clottable samples was also considered separately. A very close correlation was found between the Diagen test and the TRCHII both when the total group and clottable or nonclottable samples were evaluated (the coefficient being only slightly lower in the correlation calculated for non-clottable samples). In contrast, the correlation coefficients and the regression lines calculated for either the TRCHII or the Diagen and the Wellcotest differed markedly depending on whether the urine concentrates contained clottable fibrinogen derivatives or not. Indeed, the Thrombo-Wellcotest reacted rather poorly when the samples contained clottable fibrin(ogen)-related material.

\section{Discussion}

This study offers an evaluation of two simple and rapid techniques, using latex particles, for the measurement of fibrin(ogen)-related material. Their

\begin{tabular}{lllll}
\hline Material Studied & TRCHII & SCT & Wellcotest & Diagen \\
\hline Human purified fibrinogen (Kabi) $(100 \mu \mathrm{g} / \mathrm{ml})$ & 32 & 80 & 10 & 16 \\
Fragment D $(100 \mu \mathrm{g} / \mathrm{ml})$ & 2 & $<1$ & 40 & 4 \\
Fragment E $(100 \mu \mathrm{g} / \mathrm{ml})$ & $<1$ & $<1$ & 600 & $<2$ \\
\hline
\end{tabular}

Table I Reactivity of purified fibrinogen derivatives in different tests

${ }^{1}$ The sensitivity of the different tests was expressed as the reciprocal of the highest dilution of test material still reacting in the test. Protein concentration was determined by ultraviolet absorption at $280 \mathrm{~m} \mu$ using values of $\mathrm{E} \frac{1 \mathrm{~cm}}{1 \%}$ reported by Marder, Shulman, and Caroll (1969). 


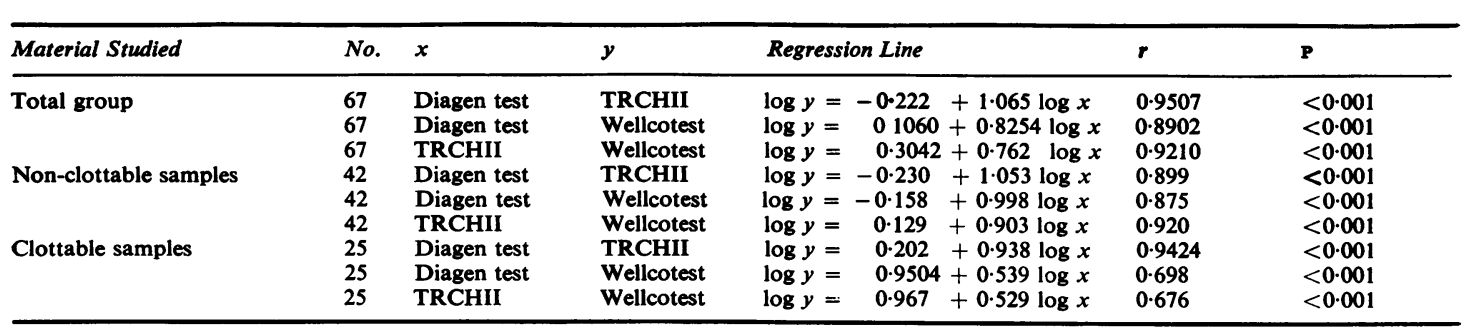

Table II Regression lines obtained by comparing the results with the Diagen test, Thrombo-Wellcotest, and TRCHII on 67 urine concentrates containing clottable or non-clottable protein

reactivity has been compared with that of the TRCHII, and of the SCT, already two widely used techniques.

Experiments with purified materials have shown that the two latex tests differ markedly in sensitivity to fibrinogen and to its derivatives at different stages of degradation. The Diagen test, like the TRCHII, would measure fibrinogen antigen $\mathrm{d}^{2}$ and therefore, as the TRCHII, be fairly insensitive to stage four digest (Molla, Donati, and Vermylen, 1973); indeed, like the TRCHII, it did not react with E and poorly with extensively degraded $D$. In contrast, the Wellcotest had a very high sensitivity to later digests, a finding also reported by Hoq and Cash (1973). The different reactivity of the two latex tests can be explained by differences of the antisera involved: in the Diagen test and in the TRCHII an antiserum directed against whole fibrinogen, in the ThromboWellcotest a mixture of anti-D and anti-E antibodies is used. The increased reactivity of the extensively degraded fibrinogen fragments, compared to unaltered fibrinogen, in the Thrombo-Wellcotest suggests that part of the anti-D and anti-E antibodies is directed against neo-antigens exposed during cleavage of fibrinogen. The existence of such neo-antigens has recently been shown (Plow and Edgington, 1973).

The different characteristics of the two latex techniques appeared also from the study of urine concentrates: the Diagen was highly correlated with the TRCHII whatever the nature of the fibrinogen derivatives present in urine, whereas the ThromboWellcotest was much better correlated with the TRCHII or the Diagen, when only non-clottable fibrinogen-related material was measured; this observation reemphasizes the relatively poor reactivity of unaltered fibrinogen in the ThromboWellcotest. A very satisfactory correlation between the Thrombo-Wellcotest and the TRCHII has been found by other workers in serum (Arocha-Pinango, 1972; Hoq and Cash, 1973) and in urine concentrates (Pitcher, 1972; Hoq and Cash, 1973). The latter authors have performed the test on urine previously $i$ treated with thrombin, therefore on samples containing only non-clottable fibrinogen derivatives. Our results thus are in agreement with their findings.

As urine both from glomerulonephritis and from transplanted patients can contain clottable protein $\frac{}{5}$ (Yatzidis, 1964; Clarkson et al, 1972; Donati et al, $\overrightarrow{\mathrm{O}}$ 1973), the combined use of the two latex techniques on non-thrombin treated urine concentrates may prove helpful in distinguishing easily the type of $\stackrel{\mathbb{D}}{-}$ fibrinogen-related material excreted in urine.

This work was supported by grant N.1216 FWGO, Belgium. The skilful technical assistance of Miss Lieve Daniels and Miss Carla Roncaglioni $\stackrel{0}{ \pm}$ gratefully acknowledged.

References

Allington, M. J. (1971a). Detection of fibrin(ogen) degradation products by a latex clumping method. Scand. J. Haemat., Suppl., 13, $115-119$.

Allington, M. J. (1971b). The latex flocculation inhibition test for the detection of fibrin(ogen) degradation products. Scand. J. Haemat., Suppl., 13, 389-390.

Antoine, B., Neveu, T., and Ward, P. D. (1969). Fibrinuria during renal transplantation. Transplantation, 8, 98-109.

Arocha-Pinango, C. L. (1972). A comparison of the TRCHII and $\frac{\sigma}{3}$ latex-particle test for the titration of F.R.-antigen. J. clin. Path., 25, 757-761.

Bouma, B. N., Hedner, U., and Nilsson, I. M. (1971). Typing of fibrinogen degradation products in urine in various clinical dis-? orders. Scand. J. clin. Lab. Invest., 27, 331-335.

Braun, W. E., and Merrill, J. P. (1968). Urine fibrinogen fragments in human renal allografts. A possible mechanism of renal $D$ injury. New Engl. J. Med., 278, 1366-1371.

Claeys, H., Molla, A., and Verstraete, M. (1973). Conversion of $\mathrm{NH}_{2}$-terminal glutamic acid to $\mathrm{NH}_{2}$-terminal lysine human $\mathrm{N}$
plasminogen by plasmin. Thrombos. Res., in the press.

Clarkson, A. R., MacDonald, M. K., Cash J. D., and Robson, J. S.N (1972). Modification by drugs of urinary fibrin/fibrinogen degradation products in glomerulonephritis. Brit. med. J., $\omega$ 3, 255-260

Clarkson, A. R., MacDonald, M. K., Petrie, J. J. B., Cash, J. D. and Robson, J. S. (1971). Serum and urinary fibrin/fibrinogene degradation products in glomerulonephritis. Brit. med. J., $\frac{\mathrm{C}}{(\mathrm{d}}$ 3, 447-451.

Clarkson, A. R., Morton, J. B., and Cash J. D. (1970). Urinary $\stackrel{\mathcal{A}}{+}$ fibrin/fibrinogen degradation products after renal homo- $\square$ transplantation. Lancet, 2, 1220-1223.

Donati, M. B., Molla, A., Michielsen, P., and Vermylen, J. (1973). $\frac{\mathrm{C}}{\mathrm{D}}$ Measurement of urinary fibrinogen-related material. Method-ฉ ological aspects. In preparation. 
Donati, M. B., Molla, A., and Vermylen, J. (1971). The tanned red cell hemagglutination inhibition immunoassay and purified fibrinogen degradation products. Scand. J. Haemat., Suppl. 13, 91-99.

Donati, M. B., Vermylen, J., and Verstraete, M. (1971). The staphylococcal clumping test for detection of fibrinogen-like material. Scand. J. Haemat., Suppl., 13, 137-143.

Dotremont, G., Vermylen, J., Donati, M. B., Van Damme, B., and Michielsen, P. (1972). Urinary excretion of fibrinogen-fibrin related antigen in glomerulonephritis; effect of indomethacin. In Proceedings of a Conference on Glomerulonephritis, Melbourne, in the press.

Haanen, C., Nováková, I., Wijeveld, P., and van Liebergen, F. (1971). Significance of fibrin split products in patients with renal failure. Scand. J. Haemat., Suppl., 13, 345-350.

Hawiger, J., Niewiarowski, S., Gurewich, V., and Thomas, D. P. (1970). Measurement of fibrinogen and fibrin degradation products in serum by staphylococcal clumping test. J. Lab. clin. Med., 75, 93-108.

Hoq, M. S., and Cash, J. D. (1973). Studies on a direct latex agglutination technique for the semiquantitation of fibrin/fibrinogen degradation products. Thrombos. Res., 2, 23-30.

Marder, V. J., Carroll, W. R., and Shulman, N. R. (1969). High molecular weight derivatives of human fibrinogen produced by plasmin. I. Physicochemical and immunological characterization. J. biol. Chem., 244, 2111-2119.
Merskey, C., Lalezari, P., and Johnson, A. J. (1969). A rapid simple, sensitive method for measuring fibrinolytic split products in human serum. Proc. Soc. exp. Biol. (N.Y.), 131, 871-875.

Molla, A., Donati, M. B., and Vermylen, J. (1973). On the antigenic determinant of fibrinogen measured with agglutination inhibition immunoassays. Submitted for publication.

Nussenzweig, V., Seligman, M., Pelmont, J., and Grabar, P. (1961). Les produits de dégradation du fibrinogène humain par la plasmine. I. Séparation et propriétés physico-chimiques. Ann. Inst. Pasteur, 100, 377-389.

Pitcher, P. M. The use of a rapid latex screening test for the detection of fibrinogen degradation products (FDP) in urine. In Abstracts of the IIIrd Congress of the International Society on Thrombosis and Haemostasis, Washington, 1972, p. 338.

Plow, E., and Edgington, T. S. (1973). Immunobiology of fibrinogen. Emergence of neo-antigenic expressions during physiologic cleavage in vitro and in vivo. J. clin. Invest., 52, 273-282.

Vermylen, J., Dotremont, G., de Gaetano, G., Donati, M. B., and Michielsen, P. (1970). Indomethacin and urinary excretion of fibrinogen-like material in proliferative glomerulonephritis. Rev. europ. Etud. clin. biol., 15, 979-984.

Yatzidis, H. (1964). Evidence of fibrinogenuria in the nephrotic syndrome. Nature (Lond.), 201, 187-188. 